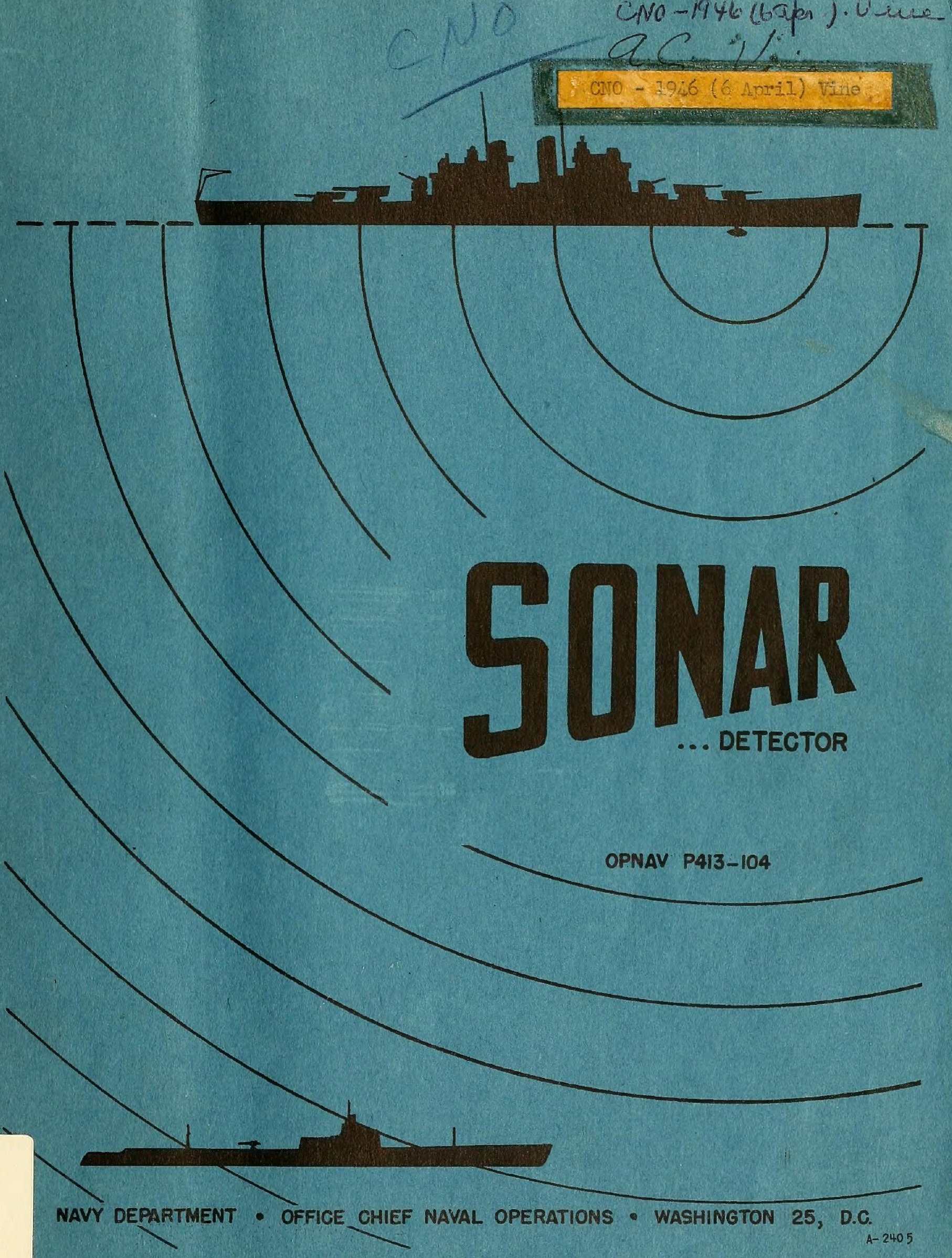




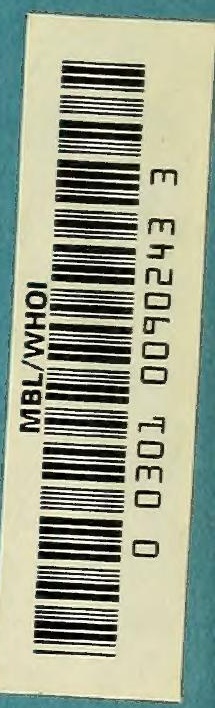


OFFICE OF THE CHIEF OF NAVAL OPERATIONS

Washington 25, D. C.

\section{SONAR - DETECTOR OF SUBMERGED SUBMARINES}

This publication was prepared by Lt. Cdr. A.P. Hilar, USN, Section Op413C4 of the Office of the Chief of Naval Operations and given to the Navy Office of Public Information for release to the Press on 6 April 1946.

The information contained herein indicates the extent to which Sonar has been declassified and may now be publicized.

Copies are being sent to those participants whose names have been submitted to the originating office and appear in this publication. Upon request by any of the listed activities, additional copies will be furnished for distribution to any non-listed activity who participated in the Sonar program.

The purpose of this distribution is to provide security guidance to activities who may wish to publicize their own wartime Sonar program.

Articles which may be prepared by any of the above activities and which are not clearly within the confines of this publication, should be submitted to the Navy Department for clearance. 

During the War's most critical period the Allies proclaimed, "History is repeating itself, as in 1914-1918, so in 1939-1942; although we shall not win the War by defeating the U-boat, we shall assuredly lose the War if we do not defeat them".

We just barely won the U-boat warfare. Neariy 1000 enemy submarines were sunk, many hundreds more damaged and thousands of their attacks frustrated because we were able to detect and locate them whether surfaced, submerged, underway or lying in wait. The Axis' tremendous respect and grave fear of our detection was declared by Gross Admiral Doenitz' top secret letter of 14 December 1943: "For some months past the enemy has rendered the U-boat war ineffective. He has achieved this objective, not through superior tactics or strategy, but through his superiority in the field of science; this finds its expression in the modern battle weapon - detection. By this means he has torn our sole offensive weapon in the war against the Anglo-Saxon from our hands".

In the majority of our attacks on U-boats, they were detected and located by SONAR. To date, Sonar has been the only effective method of detecting completely submerged submarines; other methods such as Radio, Radar, Infra-red, etc., have proven ineffective because their efforts stop at the surface of the sea. Sonar's consistent effectiveness was a major factor in the defeat of the U-boat, the U-boat which could have prevented Allied victory. The Navy has maintained its secret of Sonar throughout and between both wars. Its development has been an unspectacular, long, slow, steady conquest over the physical elements of the sea continuing in both war. and peace. The word SONAR abbreviates SOund, Navigation And Ranging, which includes all types of underwater sound devices used for listening, depth indication, echo ranging, location of obstacles, etc.

The first popular use of U/W sound was confined to navigational purposes with apparatus produced by the Submarine Signal Company about 1902. A clapper type pneumatic bell, installed on light-ship vessels, transmitted sound waves which were received by ships having a microphone on each bow. A rough estimate of the sound's direction was obtained by shifting headphones alternately to port and starboard microphones. The bell's low frequency could hardly be distinguished from various ship noises, consequently in 1907 the Submarine Signal Company produced as replacement the 540 cycle Fessenden oscillator which was essentially an electro-magnetic loudspeaker which vibrated against the water.

These equipments were useless in detecting any of the U-boats at sea during the first half of World War I. By 1916 the United States Navy had developed and installed an acoustical listening device designated as "SC" which consisted of 2 three-inch diameter rubber nipples mounted five feet apart on a T-shaped hollow pipe which terminated in a stethescope. The "T"'s were hung over the side or protruded through the bottom of Sub Chasers, which searched by stopping to listen, proceeding a few hundred yards, stopping and listening again, etc. Only a rough estimate of a target's location could be obtained; however, teamwork and triangulation by several anti-submarine vessels provided location for depth charge attacks. The charges were dropped over large areas with only small hope of scoring a kill, or of forcing the U-boat below periscope depth to prevent its aiming torpedoes or tracking ships. U.S. submarines also had the SC, the German U-boat listening device was effectively identical, and the British detectors were similar.

In 1917 the convoy system was adopted and sound equipped anti-submarine vessels escorted convoys through U-boat infested waters. From April to October 1917, about 1501 ships in 99 convoys had lost only 10 ships to the average 40 U-boats operating continually at sea during the last half of the war. 4,837 Allied merchant vessels (11,000,000 gross tons), or about 95 ships per month, were lost throughout the fifty-one months. These losses would have been much higher, had it not been for about 3,000 Allied assorted sound equipped craft which frustrated many attacks. 178 U-boats were sunk.

In the closing months of World War I the Allied Submarine Devices Investigation Committee (ASDIC) was formed to obtain from science and technology more effective underwater detection 
equipment. U.S. activity was headed by the National Research Council. A French representative named $P$. Langevin described his experiments in producing intense underwater sounds by employing a technique invented by Pierre Curie (discoverer of Radium). The technique involved passing an alternating current of about 15,000 cycles per second through a crystal of quartz which made the quartz vibrate and produce series of compressions and rarefactions in the surrounding medium and thereby propagating sound waves. Langevin had sandwiched slabs of quartz between the steel plates of his underwater transmitter which produced sound that traveled a path similar to the beam of a searchlight.

Throughout World War I the Navy's major investigations had been made at its experimental station, New London, Conn., where important techniques were developed which, however, were too late to enter the war. The SC acoustical air tube was expanded to contain six or more nipples on each bow. An electrical sonic system designated "MV" consisted of a "blister" on each bow which contained 12 microphones of the carbon button type that fed the sounds through electrical phase lines to a compensator which featured direction finding to within a few degrees. The MV and the SC became Navy standard installations. In September 1918 experiments were conducted with quartz-steel echo ranging techniques (Langevin's principles) and resulted in producing underwater sounds which were reflected from a moving target several hundred feet distant.

When World War I ended the Asdic Committee was dissolved; nations and organizations pursued their own interests. The very few first-rank scientists who remained with the Navy, despite inappropriately low wages allowed by the government, have undoubtedly been extremely loyal in their efforts to lick an unsolved technique of grave importance.

In 1919 the Sonar problems were transferred to the Naval Engineering Experiment Station, Annapolis. One important development beginning there was the Hayes Sonic Depth Finder; it contained an electro-magnet which sent sound waves to the ocean floor, received the reflection, and indicated the depth by a timing device calibrated basically at 4800 feet per second (speed of sound through water). This system was built by the Washington Navy Yard and installed in some Naval vessels.

In 1923 Sonar projects were transferred to the newly established Naval Research Laboratory (NRL) at Bellevue, D. C, where, in the Sound Section headed by Dr. H. C. Hayes, practically all of the Navy's peacetime Sonar research and development was carried on. The equipments developed at NRL in conjunction with the Bureau of Ships Sonar Section and progressively installed in Naval vessels during peacetime, constituted the primary Sonar techniques which were employed throughout World War II.

About this time certain terminology was adopted; "Sonic" sound covered the audible range from 16 to 15,000 cycles (vibrations) per second, and frequencies above the sonic band were referred to as "Supersonic". (Average ears respond from about 40 to 15,000). Propellers create sonic and supersonic sounds).

Work on the acoustical sonic system was continued at low priority since desired signals (Propeller noise) suffered severe loss during transfer from water to air. Comparatively little signal strength is lost by transfer from water to electrical microphones and then to telephone head sets; therefore, development of electrical sonic systems was advanced in order to equip ships with the best available apparatus. However, sonic systems were generally unsatisfactory because various water noises caused by own propellers, own ships movements, etc., resulted in considerable interference. Therefore greatest emphasis was on the supersonic echo ranging experiments - the advantages are many; the signal is amplified electronically (vacuum tubes), employment of supersonic frequencies narrows the reception range to a selective band thereby eliminating much of the oceans inherent sonic noises, and directivity of reception is confined to selective narrow pie-shaped sections. To these improved listening techniques are added the "ping-echo" features.

The first experimental echo ranging sets operated at frequencies between 20,000 and 40,000 cycles per second. These "supersonic" voltages were generated by a transmitter that fed the transducer (combined radiating and receiving unit) which protruded through the ship's 
bottom. The four-inch thick transducer consisted of quartz slabs sandwiched between steel discs about sixteen inches in diameter. It "pinged" out $1 / 4$ second pulses of energy which traveled horizontally in a cone-shaped path. When part of the sound wave struck the target submarine, a small portion of the energy was reflected back to the transducer which fed the "echo" through an electronic amplifier to earphones and a range (distance) indicator. The direction in which the transducer was facing indicated the target's bearing. Only about twenty watts of power was transferred to the water and echoes were obtained from a few hundred feet distance. The equipment gave results while the ship in which it was installed was underway at speeds below 3 or $4 \mathrm{knots}$, and in 1927 several Naval vessels commenced sea trials with the NRL quartz-steel echo ranging Sonar. These echo ranging inventions are considered the greatest contributions to the science of underwater detection.

About 1927 the Submarine Signal Company was producing water depth indicators called "Fathometers". The transmitter consisted of an electro-magnet which banged a piston against a diaphram facing the ocean bottom thereby emitting a 1000 cycle sound wave which was reflected from the ocean bottom to a button type microphone. This "echo" was fed to a calibrated scale where neon light flashes indicated the depth. Fathometers were eventually installed in most Naval vessels.

By 1929 NRL had produced a listening Sonar which replaced the acoustical SC tubes in submarines. It was designated as JK and was in effect the listening portion of our echo ranging Sonar; thus, the listening head had the shape of current transducers, but in place of the quartz crystals used in echo ranging, the newly developed Rochelle Salt Crystals were employed since they were comparatively more sensitive. The Navy Yard at Washington produced the JK's for all the submarines we then had. The transducer was mounted on the top side thereby permitting use of the Sonar only when the submarines submerged. The JK increased listening ranges to about 5 miles under average water conditions and gave bearings accurate to within a few degrees. Shortly afterwards they, were modified by addition of a small transmitter which provided a feature similar to the "ping" feature in echo ranging; this feature was used for communication between submarines. Also, a few JK's were modified for underwater voice communication. For many years the JK remained as the most valuable listening equipment in submarines.

About 1931 NRL developed the QB echo ranging Sonar for submarines. It was practically identical to our surface vessel Sonar except that it employed Rochelle Salt Crystals instead of the quartz crystals used in surface ship transducers. The QB's (in addition to the JK's) were subsequently installed in new construction submarines where the transducer protruded through the keel, thereby enabling use of the $\mathrm{QB}$ whether the submarines were surfaced or submerged.

Thus by 1933 the Navy Yard at Washington had produced about a score of quartz-steel echo ranging for destroyers and was engaged in production of about $60 \mathrm{JK}$ listening Sonar for submarines, and the Submarine Signal Company commenced production of about 30 QB echo ranging Sonar for submarines. These equipments operated satisfactorily up to ship speeds of about 5 knots beyond which the roar and crackle of water noises drowned out target noises and echoes. To reduce the turbulence caused by the movement of the flatfaced transducer through the water, NRL produced a spherical cover about 19 inches in diameter, made of sound transparent rubber developed in collaboration with the Goodrich Company. This "dome" permitted 10 knot speeds before water noises became excessive, and was subsequently incorporated in all our transducers.

About this time a transducer was invented in which magneto-striction tubes replaced the quartz or salt crystals. These tubes were small electromagnets consisting of a 3 inch long - $3 / 8$ inch diameter nickel alloy hollow tube, àround which was wound a coil of wire. The tubes elongated or contracted when their magnetic flux was changed. The electrical energy from the transmitter caused movements of the magneto-striction tubes which resulted in vibrating the diaphram of the transducer, thereby emitting "pings". Conversely, when any sound waves which struck the diaphram caused a change in the magnetic flux of the magneto-striction tubes, an electric current was generated which resulted in signals corresponding to the sound source, i.e., propeller noises, echoes from pings, etc. In 1934 the Bureau of Ships designed, and the Submarine Signal Company commenced production of, the magneto-striction echo ranging equipment which were subsequently installed in 8 destroyers and 6 submarines per year. The Submarine Signal 
Company then also began producing magneto-striction echo sounding equipment, for measuring water depth, which gradually replaced the Fathometer in Naval vessels, and the RCA produced two echo ranging equipments which were used experimentally.

The handful of zealous Sonar workers were now busily engaged in continuing developments to improve Sonar and investigating Sonar's operating medium - the ocean. Information was needed concerning the loss in intensity of sound traveling between two points, reflecting properties of targets, character and masking properties of extraneous background noises, effects of temperature changes, and methods of making absolute underwater sound measurements. Data on these factors was essential to the design of efficient equipment. NRL began studies in detail of these water propagation characteristics on a purely scientific basis. The Bureau of Ships, NRL and fleet units began discussions of sound-in-water phenomena with the scientists of the Woods Hole Oceanographic Institution and the Scripps Institute of Oceanography.

In 1934 two destroyer divisions and two submarines based at San Diego were engaged in training of Sonar operators and formulating "Sonar Tactics Doctrine" to prescribe the basic procedures of employing Sonar in convoying. Each Sonar may begin searching a given sector by listening on the transducer, moving it a few degrees, listening, etc., until the sector is covered, each escort continually sweeps his assigned sector of the ocean. If a submarine's noise or propellers are heard, or it is suspected that the submarine is lying-to, the Sonar "ping-echo" feature may be employed. Sometimes the search is conducted entirely by pinging. Once an echo is received, several escorts usually maintain Sonar contact with the submarine while they attack by Sonar navigation. The submarines' Sonar can usually hear pings at distances greater than from which ping echoes can be obtained; thus if he remains distant (where pings do not reach) or moves further away, his attack on the convoy is frustrated, if he moves toward the convoy the pings contact him and the submarine finds itself on the spot. If the submarine fires torpedoes, they may be heard by Sonar and perhaps avoided by quickly turning the surface ship.

Early in 1939 it became apparent that training of personnel could not be handled as a byproduct of engineering and tactical tests. Consequently the U.S. Fleet Sonar School at San Diego was established in order to increase training facilities. The Radio and Sound School at NRL also expended its technical training in Sonar. Various instructional equipments including electronic anti-submarine attack teachers for duplicating seagoing training were being developed and used. To provide more equipments and training, the Radio Corporation of America was placed under contract by the Bureau of Ships and commenced production of echo ranging Sonar in the summer of 1939 . The value of Sonar was becoming keenly appreclated.

Thus by 1939 Sonar had progressed remarkably since 1918. The capability of World War I listening apparatus was limited to indicating the presence and general area of U-boats that were underway. Now, as the World was on the brink of another war, in which the U-boats were to take a major role, we had ships equipped with Sonar systems capable of detecting U-boats whether they were surfaced, submerged, underway or lying still; furthermore, we could tell their bearing, distance, and almost exact location. This achievement was literally due to a few individuals whose zeal was unthwarted by many disappointments.occasioned by lack of adequate funds for research and development, insufficient appropriations to equip more than about a dozen ships per year, and limited fuel allowance which prevented ships from conducting more tactical training exercises. The naval officers who pioneered Sonar pleaded in vain to have these deficiencies adjusted. In spite of this, their enthusiasm and perseverance resulted in Sonar being one of the few exceptions to the generally accepted rule that new wars are started with the equipment in use when past wars ended. The Navy's job of "preparing for war in peacetime" had been done in the Sonar field to the limit of available appropriation.

When World War II began, neither Axis nor Allies were prepared for intensive submarine warfare. The Germans had only about twenty 500-ton and ten 750-ton oceangoing U-boats. The British had fitted their "ASDIC" (British word for Sonar) on 165 destroyers, 34 small patrol craft, and 20 trawlers, and the United States had about 60 destroyers fitted with echo ranging Sonar. Contracts were made with the Submarine Signal Company to increase production of echo ranging equipments in order to equip our old destroyers within six months. 
When the United States indicated the intention of making common cause with the Allies, there was resumption of exchanging scientific knowledge. Sonar and Asdic scientists became aware that they had paralleled developments and possessed practically identical equipment. The primary differences were: British Asdic transducers contained quartz-steel while U.S. Sonar had magneto-striction; British Asdic domes were streamlined while ours was a sphere; British Asdic ranges were permanently recorded on a range recorder while Sonar ranges were indicated on a dial.

The range recorders are a valuable aid ir conducting an attack; we obtained samples from Britain and the Sangamo Electric Company started producing our own types. The streamlined dome increased the ships speed at which Sonar could be effectively operated from 10 up to 15 knots; we adopted it from Britain, Canada furnished some equipment, then the Submarine Signal Company, the Rice-Barton Company, and the E. G. Budd Company commenced production of U.S. equivalents. Britain also furnished some ASDIC Electronic Attack Teachers which provided realistic methods of maneuvering models of an Asdic fitted escort attacking an evasive U-boat within the confines of a Sonar classroom. These Asdic Teachers added to the growing number of Sonar Teachers.

Thus began a technical liaison which quickly enveloped British.Asdic and American Sonar scientists, officers, technicians, etc., into a family known to each other by first names. Research, development, ideas, etc., were exchanged, U.S. observers were stationed at British Admiralty Anti-U-boat activities, Britain had representatives at U.S. Navy activities, both countries exchanged visits to laboratories, etc.

The first year of World War II was a typical blitzkrieg. The Norway invasion in April 1940 provided more U-boat bases and Italy brought about 100 submarines into the war, 60 were oceangoing. The Axis' use of French ports, starting in July 1940, extended the U-boat's westward range. The spotting of approaching convoys by French based aircraft compelled Allied ships to take longer routes north of England. The obvious preparations for invading England during August of 1940 required British anti-submarine ships to guard the coasts of the British Isles. This strategy was timely - Gross Admiral Doenitz recently stated that insufficient opposing German naval strength caused "postponing" the invasion. The diversion of Asdic equipped escorts from convoy duty resulted in U-boats reaching their highest effectiveness - each sinking about 10 ships per month.

At this extremely critical time the British obtained 50 World War I destroyers from the United States in exchange for lease of British territory in the Western Hemisphere which we used as defense bases. The old "flushdeckers" were equipped with echo ranging Sonar, and a hand-picked group of our best Sonar operators instructed British Asdic Ratings in the use of the U.S. equipment. Encouragement spread through the Royal Navy's anti-submarine fleet; the Asdic teams added their range recorders to our Sonar and did very well - one set operated continuously from New York to the Irish Sea (21 days) and netted a U-boat.

By December 1940 the Allies' original forty million gross tons (about 8,000 ships) had been reduced by $41 / 2$ million g.t., 1201 vessels, an average of 80 per month, had been sunk by the enemy. About 2500 ships per month had been convoyed by about 600 Asdic fitted escorts of which half were oceangoing, the others were small patrol craft. The Germans now had about 45 U-boats, an average of 10 operating at sea continually. $27 \mathrm{U}$-boats and 17 Italian subs had been sunk, averaging 3 per month.

During the winter of 1940-1941 the West Coast Sound School had been expanded and the Sound School at Key West established. Courses were given prospective commanding officers of anti-submarine vessels, enlisted men were taught operation and maintenance of Sonar equipment, and destroyers were used to train "Attack Teams".

The mobilization of the nation's scientific and technical manpower had resulted in establishing the "Office of Scientific Research and Development" (OSRD). The National Defense Research Committee (NDRC), one of OSRD's principle agencies, formed Division VI headed by Dr. J.T. Tate, which in April 1941 began a thorough investigation of submarine detection on the 
premises that lack of basic scientific information was a serious handicap in the design and effective use of equipment.

A laboratory was established at San Diego under the University of California Division of War Research, and sponsorship of formal work at Woods Hole Oceanographic Institution was taken over. Several research groups were set up under Columbia University Division of War Research, including a Theoretical Analysis Group, the Underwater Sound Reference Laboratories, and a Sonar Laboratory at New London (resulting in the establishment of the USN Underwater Sound Laboratory, New London). The services of the Scripps Institution of Oceanography were enlisted, and contracts were made with Massachusetts Institute of Technology, Harvard, University of Iowa, etc. In addition, NDRC field groups were stationed in and visited all active theaters including Britain. (Names of universities, organizations, industries, etc. mentioned herein happened to be convenient in this presentation; however, contributions by many others not mentioned were, in many cases, of equal magnitude and value)

Prominent scientists, including Nobel prize winners, sought more effective means of finding submarines. Extensive experiments were tried off San Diego by the California Division of War Research with very powerful underwater search lights and flares. Although the light could be seen for several hundred feet in the sea, it was impossible to detect outlines of submerged object because the light was so badly scattered and diffused. Various other types of electrical and magnetic detection methods were also tried by scientific and engineering groups in the Atlantic and Pacific without much success. The sea proved practically impenetrable to long and short radio waves, radar, infra-red, ultra-violet and other types of radiation. Scientific and engineer ing effort was thenceforth concentrated on further development of the Navy's existing underwater sound techniques. Britain contributed her entire history on scientific investigations of underwater sound.

During the summer of 1941, U-boats began "wolf pack" attacks and raided off Greenland and Newfoundland. An east-bound convoy was attacked before escorts joined and ten ships were sunk. About July the British began escorting convoys entirely across the Atlantic even though fewer Asdic fitted escorts could be assigned each convoy. Then the President announced that the safety of our country required the basing of forces in Iceland. In September the United States declared its policy of protecting all ships carrying Lend Lease materials and U.S. Navy vessels joined the escorts. The U.S. destroyers, KEARNEY and REUBEN JAMES, were torpedoed by the Nazis.

About this time the British captured the U570, one of the only two U-boats taken "alive or dead" during the war. She proved to be a valuable source of information. One of the U-boats sound equipment is an underwater telegraph system containing a pair of small transducers containing electro-magnets composed of four-inch lengths of nickel stampings surrounded by a magnetising coil. The second set is a long range listening device containing an array of 24 threeinch diameter microphones on each bow which are fed through a phasing network to an amplifier and earphones. It is not accurate enough to fire torpedoes by, but convoys could be heard up to about ten miles away under good water conditions. No echo ranging search set was on board apparently either the Nazis had not developed any or else they wisely had calculated that pinging submarines could be detected easily. The Asdic Sonar brotherhood conducted trials with U-570 sound equipment and promulgated their analysis to Allied Navies and Merchantmen for use in countering U-boats' tactics.

During 1941 another 1118 ships had been sunk, averaging 93 per month. The Germans now had about 200 U-boats, an average of 32 operating at sea continually. The Asdic-Sonar fitted escorts totalled about 800 of which 500 were oceangoing. 30 U-boats plus 15 Italian subs had been sunk, averaging 4 per month.

When the United States entered the war, our 170 destroyers were the only U.S. Surface craft fitted with echo ranging Sonar; $3 / 4$ of them were engaged in cross-Atlantic convoying; the others were employed in the Pacific. Our unescorted Atlantic seaboard shipping was slaughtered at the rate of 75 ships per month by an average of 38 U-boats of which we killed about 3 per month. Many of these sinkings occurred within sight of our coasts. The Japs' 75 subs were sinking 10 ships per month in the Far East. These tremendous losses might have been greater judging from Gross Admiral Doenitz' statement, "Additional U-boats were, unfortunately, not 
available because we did not have advance warning of the Japanese attack, which was a complete surprise to Germany's political and military leaders."

Meanwhile, the Bureau of Ships was equipping all available PT's, sub-chasers, motor boats, yachts, etc., with lightweight Sonar. Production facilities at the Submarine Signal Company and RCA were expanded greatly; additional contracts were made with Bell Laboratories, Western Electric, Bludworth Company, and others. The British-lend-leased us 10 Corvettes, having first trained our crews in Britain to use the Asdic; we obtained 24 Asdic-fitted small patrol craft from Canada, and by March 1942, began our coastal convoying with a pitiful small number of ships and land-based planes.

During this period the Roosevelt-Churchill team planned the eventual invasion of Europe the two Navies were to deliver vast armies and tremendous supplies. But, U-boats were sinking ships faster than we replaced them, and we were losing the Battle of the Atiantic. Our success in attacking U-boats after we detected them was less than 5 per cent - 95 out of 100 got away. Sonar was detecting the U-boats, but in the crucial moments of the attacks, something was inadequate.

To find the solution the Navy Department assigned to NDRC (Div. VI) the project of providing statistical analysis of past operations, theoretical detailed studies of tactical doctrines, operational analysis of Sonar attacks and of equipment and weapons in order to prescribe for their best use and assist in improving their design. Accordingly, the Anti-Submarine Warfare Operational Research Group (ASWORG) headed by Dr. P.M. Morse, was established with representatives in offices of practically all fleet units headquarters including the British Admiralty. Britain's Operational Analysis Group, which had been furnishing information to the Commander, U.S. Naval Forces Europe Technical Staff in London, also furnished ASWORG with statistics of the Royal Navy's 2 1/2 years war experience. We adopted the best known methods of convoying, Asdic screening and searching, attacks on U-boats, etc., and our attack successes increased. Likewise, our ships reported attack details to ASWORG whose detailed analyses soon paid dividends.

Another expedient was the establishment at Boston of an Anti-Submarine Warfare School in addition to the schools at San Diego and Key West. Instruction given was in three categories: training enlisted men as Sonar operators, training officers to interpret and apply the Sonar data, and training crews to function automatically and efficiently as a coordinated attack team. The gratifying results eventually led to establishing about forty similar activities which were attended, in addition to enrolled trainees, by some crews of ships lying in port between voyages. Sonar attack teams spent their infrequent shore leaves on a typical Postman's Holiday.

College professors and experienced educators developed high-speed mass indoctrination methods for Sonar students. The University of California Division of War Research (UCDWR) devised a method of psychological selection of Sonar operators since men differed widely in ability to hear echoes above reverberation and background noise. School equipments developed by the NDRC team of Harvard, Columbia, UCDWR, and others, included several types of listening teachers, sound classification trainers, echo repeaters, bearing and ranging recorder interpreters, torpedo detector devices, etc. A valuable contribution was phonograph recordings of actual U-boat sounds which were furnished by the British. Complete Sonar equipments were employed, electronic attack teachers displayed escort versus U-boat maneuvers, and graduate training was done at sea using towed underwater targets and actual submarines.

In the summer of 1942 the British added an Anti-Submarine Warfare unit to the British Admiralty Delegation in Washington in order to maintaín close liaison on the conduct of the antiU-boat warfare and technical developments. Eventually about 700 British Officers and Ratings, while awaiting completion of Britain's share of the 500 destroyer escorts we were building, attended our fleet sound schools. These experienced British U-boat killers greatly influenced our training methods.

At sea we were assuredly losing the war. Convoys required 70 days for Atlantic round trips. During June 1942, an average of 48 U-boats operating at sea continually sank 143 ships. 
Each U-boat was "living" long enough to sink 20 ships. When depth charged, they did not break as did World War I riveted U-boats, their welded construction provided elasticity and only very close or direct hit explosions killed them. They were capable of diving to 600-foot depths. They remained at their sea stations for very long periods as they were being provisioned by "cow" or supply U-boats, each "cow" furnished supplies ta about 10 U-boats. The original German "magnetic firing" torpedoes which were designed to be exploded by the target ships influence, proved inefficient (several bounced off HMS NELSON without exploding) and were being replaced. One of the new types was deșigned to explode by impact on the target, another was the acoustic torpedo which "homed" itself on the targets propeller sounds, and a third type "looped" within convoys thereby increasing the probability of a hit.

One of the basic reasons for our difficulty was the tremendous shortage of escort vessels of which literally hundreds were required to protect the allied communications lines which were stretched over thousands of sea miles. Also, the lack of success in individual attacks on U-boats was known to be due in part to the need for better training for the thousands of officers and men required to man the escorts. However, during that year (1942) all the training ingenuity, shipbuilding skill, and scientific effort had been massed by the Navy to meet the situation.

The analysis groups submitted reasons for our poor successes in attacking U-boats. At critical phases Sonar lost contact because: (1) U-boats hearing our pings becoming louder and faster, judged the moment of our attack and therefore went deeper - below the Sonar beam. The remedy was the "creeping attack", delivered by 2 escorts - the first maintaining contact at a fixed range and ping interval while coaching the second attacker at very low speed over the U-boat by signals, (2) U-boats created disturbances by backing down, turning sharply, or ejecting chemicals that generated clouds of bubbles, which momentarily reflected strong echoes; these echoes simulated a second or third U-boat thereby confusing the attackers while the hunted sneaked off behind his false targets. The counter-measure was to promulgate information by radio on this U-boat trick, and to issue instructions to maintain "doppler" contact (obtained only from moving targets). Sonar-Asdic men soon learned to read through "false" targets; erroneous attacks on bubble clouds ceased.

The Scientific Research Groups submitted certain confirmation of the pre-war work of our naval officers and scientists, namely: (1) Sound travelling in warm surface water bends sharply downward when it passes through a thermocline (a region where temperature decreases sharply with depth) and results in very weak echoes being returned from submarines beneath the thermocline, (2) That thermoclines may cause loss of Sonar contact, (3) That U-boats may hide under thermoclines, (4) That a shipborne, cable-lowered bathythermograph for recording temperatures and pressures to locate thermoclines could be used to detect these ocean effects. These confirmations, and the bathythermograph together with prediction tables and tactical rules were supplied to ships for use in the predicting of maximum echo ranges, spacing between escort vessels, and interval between successive Sonar pings (since longer distances require longer time between pings).

The engineering groups had enlisted the aid of another score of manufacturers and furnished: (1) a gyro-controlled "Maintenance of True Bearing" device to keep the Sonar beam directed on the U-boat during an escort's maneuvers or turns; (2) an electronic "Bearing Deviation Indicator" scope to indicate visually whether the Sonar beam tended to lose contact due to the operator moving the beam either to the right or left of the U-boat, (3) a "Reverberation Gain Control" which reduced the heavy reverberations resulting from the Sonar's sudden pings which cuase the surrounding water to act like a large empty hall with bad acoustics. This control also reduced undesirable interfering echoes from seaweed, shallow water bottoms, tidal currents, wakes, etc.

The effectiveness of the improved Allied anti-submarine measures was demonstrated when history's greatest invasion armada of about 1065 assorted vessels made passage in November 1942 from United States and United Kingdom ports to the coasts of North Africa. Although some 40 U-boats were lying in wait, they sank only 23 ships during November. Gross Admiral Doenitz observed, "The surprise Anglo-American landings in North Africa called for a concentration of U-boats on both sides of Gibraltar. Every U-boat that could reach these waters within 10 days 
was mustered. Defense in these African waters was very effective and U-boat losses were correspondingly high."

During 1942 some 1573 ships had been sunk; the average was 131 per month. The Germans were now keeping an average of about $80 \mathrm{U}$-boats continually at sea out of their pool of 360 . The Sonar-Asdic fitted escorts totalled about 800 oceangoing types. 82 U-boats, plus 20 Italian and 16 Jap subs had been sunk, averaging 10 per month.

Early in 1943 the general locality of surfaced U-boats which transmitted reconnaissance data by radio signals was detected from long distances by High Frequency Radio Direction Finders installed ashore in America and Britain as well as by equipment installed in escorts. Such localities were searched by land-based and escort carrier planes equipped with Radar, which was becoming increasingly effective since U-boat Radar intercept.receivers were unable to detect the surprisingly short waves employed. Radar contact was lost once the U-boat submerged (in about forty seconds) Planes parachuted several floating expendible Radio-Sono Buoys whose suspended underwater Sonar hydrophones could detect U-boat noises which activated its radio transmitter. Such transmissions, when received in the planes or nearby escorts, indicated the U-boat's area which could then be swept by Sonar-Asdic fitted escorts for accurate location and attack.

In the early summer of 1943 an average of about 120 U-boats were operating in the Atlantic. U-boat packs were frequently out-numbering the escorts by 2 to 1. Two convoys traveling close together were attacked by about 40 U-boats which sank 20 ships. Another convoy of 33 ships protected by 8 escorts was attacked by a pack of about $20 \mathrm{U}$-boats which sank 12 ships during the midnight hour. The same pack reattacked the next night - but, none of the remaining 21 ships were lost, 24 individual U-boat attacks were frustrated, and at least 5 U-boats were sunk. The escorts had been augmented by about a score of the newly built destroyer escorts and a dozen "baby flattop" aircraft escort carriers. Planes were sinking U-boats and also frustrating their attacks by forcing them to submerge. Allied aircraft patrols commenced 24 hour daily coverage over the Bay of Biscay; this intensified offensivehad the effect of keeping U-boats submerged while they were in transit to and from their French bases thereby decreasing the time they could remain at sea. During May, June, and July we sank 108 U-boats. The crisis, or turning point, in the "Battle of the Atlantic" was being enacted.

Typical battles which ranged between the U-boats and our escort killer groups are exemplified by the sinking of the U-233 by the "Baby-Flattop" USS CARD and the destroyers, USS THOMAS and USS BAKER.

First contact with U-233 was made on 2 July when CARD aircraft sighted a swirl about two hundred miles off Halifax. Radio-Sono Buoys were dropped around the swirl and contact with the U-boat was maintained throughout the day, although the intermittent bad weather required the recalling of aircraft necessitating cessation of listening to the buoys on several occasions. Two destroyer escorts were called in and conducted a Sonar search in the area without results. Sonar conditions were very poor, and from 2 to 5 July bad weather prevented further aircraft search.

On 5 July, CARD, BAKER, and THOMAS were still searching the area. The BAKER made Sonar contact and streamed her Foxers to avoid acoustic torpedoes from the U-boat. At 1913 CARD dropped a load of depth charges. At 1920 BAKER made the second attack with depth charges which resulted in a huge geyser of water mixed with oil.

At 1925 Sonar contact was regained. At 1931 the radar operator reported a large pip at twelve-hundred yards. Simultaneously, the bow of the U-boat broke the surface at a steep angle on the radar bearing. Accurate and heavy gunfire was opened at a range of twelve-hundred yards. BAKER then passed ahead of the U-boat and fired her port K-guns. The charges straddled and detonated close aboard on both bows of the U-boat. Gunfire continued and at 1941 BAKER again passed close ahead of the U-boat and dropped a pattern of depth charges. At this time, some of the U-boat's crew were observed in the water astern of the U-boat and others were abandoning ship. 
The THOMAS bore down on the enemy, firing point blank, and rammed the U-boat just aft of the conning tower, U-233 then sank beneath the THOMAS.

The 30 U-boat survivors who were recovered offered the following information: In the early evening of 5 July, U-233 came up from her usual travel depth of about 250 feet to about 100 feet in order to service a torpedo or torpedo tube. Suddenly a high whining sound was heard throughout the U-boat followed by propeller noises passing overhead. Depth charges burst all around which severely shook the entire boat; glass was smashed, and loose equipment flew all over the boat. The boat descended rapidly to about 400 feet at which point water entering the after compartment caused her to become stern heavy. A torpedo on the loading rails suddenly slid into the tube with such violence that it disemboweled one of the torpedo men who happened to be in the way.

Just what happened in the after part of the boat is unknown; not a single man survived. The U-boat continued to sink by the stern at an alarming angle, was completely out of control, and chlorine gas from the after compartment was spreading throughout the boat. Ppssibly at this moment the door between the control room and the diesel room was sealed off. Another pattern of depth charges caused further damage. The order was given to blow all tanks and the U-boat surfaced.

As the U-boat reached the surface she was attacked with very accurate fire. The chief engineer opened the conning tower hatch and the top of his head was promptly blown off. Successive crew members attempting to leave by this hatch added to the pile of dead which littered the conning tower. Shells and machine gun bullets tore through the plating around the conning tower, and one shell appears to have penetrated the pressure hull and exploded in the petty officers' living quarters killing everyone and filling the compartment with acrid fumes.

The 30 survivors who had jumped overboard had left by the forward hatch. Within 15 minutes after surfacing, the bow of $U-233$ rose high into the air and sank almost vertically.

In the summer of 1943 our efforts in tracking U-boats, routing convoys, assignment of "never enough" escorts, use of weapons, methods of attacking U-boats, etc., were centralized in the Tenth Fleet created in Washington by the Commander in Chief, United States Fleet with himself as its commander. The existing Atlantic Fleet Anti-Submarine Warfare Unit formed the nucleus; NDRC, NRL, Navy Bureaus, ASWORG Universities, and other organizations contributed experienced officers, scientists, analogists, technicians, etc. Play-by-play reports of the war, received constantly by radio, were fed into IBM machines whose statistics dictated formulation of tactics, doctrines, training, weapon design, etc. Many all-night "poker games" were endless; thermos corks popped out black coffee, the chips were U-boats and ships, the betting stakes were humanities highest - the Four Freedoms, the cards were face up on an enormous chart showing convoys, escorts and U-boats, each play was made with "sweat, tears, and blood", and when the enemy dealt from under the water - our ace in the hole was Sonar.

The Tenth Fleet and British Anti-U-Boat Division analysis resulted in increasing the convoy size from 40-50 ships to about 90 without increasing the number of escorts - their effectiveness was increasing. Plane/ship coordinated attacks were improving. Towed "Foxers" or underwater noise makers attracted acoustic homing torpedoes away from propellers. Faster sinking stern-dropped 300-pound depth charges reduced critical seconds of sinking time during which U-boats take evasive action. "Hedgehogs" and "Mouse-traps", mounted on escort forecastles, further reduced blind time by projecting a pattern of thirty-pound charges several hundred feet ahead, which upon striking the water covered large circular area and exploded only by contacting the U-boat thereby indicating a hit which usually results in a kill. The accumulated instruments which appended the Sonar and which looked like Christmas tree ornaments had been incorporated into the "Console Sonar" which contained new features including: detection of mine fields, calculation of U-boat depths with the echo sounder, indication of oncoming torpedoes traveling as high as $40 \mathrm{~m} . \mathrm{p} . \mathrm{h}$., and accessories which indicated to "plot" accurate ranges, bearings, time to fire weapons, etc. Unescorted fast ships were being fitted with hydrophone torpedo detectors; one Merchantman detected an oncoming torpedo, avoided it by turning the ship, then rammed and sank the U-boat. 
In September 1943 the Axis midget craft, 1 and 2 man "human torpedoes" were employed against the Allies invading Italy. They failed to penetrate the Asdic screen, were detected and destroyed. Five days later 29 subs were taken when Italy surrendered. A captured Italian escort was found to be fitted with a German echo ranging equipment which the Axis had begun installing. The equipment was primarily a detector and did not provide the many attack and ship control features contained in Asdic-Sonar.

In the fall, says Admiral Doenitz, "The boats were ordered to remain on the surface when attacked by aircraft and to cooperate in fighting off the attack. They were then to attack and break up the destroyer screen, with acoustic torpedoes and, in the third phase of the battle, attack the convoy now deprived of its protection." But due to the disaster suffered by the U-boats, he said, "It was, therefore, finally clear that surface warfare for U-boats had come to an end." Surface exposure to aircraft and radar detection resulted in the U-boat arm losing about 50 per cent of its offensive power and being driven from the surface. Continuous submerged operation was envisioned in Gross Admiral Doenitz' top secret order of December 1943 which reads in part, "It is essential to victory that we make good our scientific disparity and thereby restore to the U-boat its fighting qualities." Consequently, German scientists who had been drafted to shoulder rifles were recalled from military service to help create the "Naval Scientific Directional Staff".

During 1943 only 598 ships had been sunk, while 219 U-boats, 22 Italian and 22 Jap subs were sunk, averaging 22 per month. During the winter of 1943-44 the average 60 U-boats at sea took extreme care to avoid detection and operated mostly submerged - but, detection by Asdic-Sonar was becoming increasingly effective, and we began sinking more U-boats than they sank ships. By April 1944 the Battle of the Atlantic had been decisively won. Our scientists had been shouldering detection problems as their contribution to the enormous Navy effort.

Japanese shipping was now being annihilated. Jap escorts which had been using mostly hydrophone detectors now began greater use of crude echo ranging equipment. Our submarines used bathythermographs to hide under thermoclines, and also for regulating ballast water, since a submarine's buoyancy depends on water density which in turn depends on water temperature. Hydrographic charts were provided to show the type of bottom in various operating areas since submarines are more likely to be detected over sandy bottoms which reflect sound than over mud bottoms which absorb sound. Maps indicated the areas in which intense shrimp noises probably would mask the sounds created by submarines. Our submarine echo ranging Sonar had been augmented by: (1) a topside listening hydrophone consisting of a 3 foot long 2 inch diameter magnetostriction tube having excellent directional accuracy on sounds up to about 10 miles distance in average water conditions; (2) a shipboard listening trainer, attached to the Sonar to provide practice in estimating speeds of various ships by their propeller rhythm; (3) other Sonar equipment which facilitated submerged excursions into Japanese held waters including Tokyo Bay.

On D-Day (June 6, 1944) when the Allies invaded the Normandy beaches, the invasion waves were led by small naval scout craft equipped with "Beach Obstacle Locators" containing an echo ranging Asdic whose recorder traced the outlines of the beaches. Obstacles (mines, fencing, etc.) were cleared by demolition out of the path of landing craft. The invasion forces were blanketed by such heavy air coverage and a Sonar screen so tight that no ships were lost to U-boats until the end of June when the 7 ships they sank had cost them 21 U-boats.

Up to this time, the U-boat had acted as a submersible torpedo boat, spending much of its time surfaced, visible by eye and Radar, and audible to radio interception and radio direction finders. But the U-boats' tactics were revolutionized in the summer of 1944 when they were equipped with the "Schnorchel" extension stack, which expelled diesel exhaust and drew in fresh air. The Schnorchel stack was about the same height as the periscope and permitted: (1) operation on diesel propulsion while submerged to periscope depth for which batteries were formerly used, (2) re-charging batteries at periscope depth which previously required surfacing fully, (3) six knot speeds at submerged periscope depth instead of about 3 knot speeds formerly employed to conserve batteries. The U-boats took up stalking positions at focal points of convoy routes, listening while lying on the bottom, from where they attacked by blindly firing acoustic and looping torpedoes into passing convoys. Periodically they came to Schnorchel depth to replenish their air and re-charge batteries. Admiral Doenitz' comment on Schnorchel tactics was, 
in part, "The strain on crews who remained submerged as long as seventy days was surprisingly light."

The top of the Schnorchel stack contained an intake-exhaust valve which measured about $11 / 2$ ' by $3^{\prime}$. This valve and the periscope is usually the only exposure above water while the U-boat operated at Schnorchel depth. The valve was covered with anti-radar material making it practically invisible to Radar. Visual detection range on the Schnorchel was only about a mile or two in daytime and practically nil at night. The U-boats literally maintained "radio silence" thereby depriving the Allies of radio direction finder detection. Effectively, the Schnorchel had neutralized our anti-submarine air offensive and defeated our surface detection. But, whether schnor chelling, submerged or bottomed - the Asdic Sonar teams detected and located the U-boats. Thus during 1944, the 202 U-boats and 51 Jap subs which were sunk averaged 21 per month, while the 134 ships they had sunk averaged only 11 per month.

During the winter of 1944-45 an average of 40 of Admiral Doenitz' continually submerged U-boats, plus scores of submersible midget U-boats had concentrated in the Channel areas against the bridge of ships carrying reenforcements to hard-pressed Allied land forces, fighting the battle of the Bulge. Their operations during the last four months of the European war resulted in sinking only 56 ships while 88 U-boats plus about 100 midgets were sunk. The submerged Nazis had been swept out by the "Killer Group" escorts equipped with Asdic-Sonar which the Allies had developed to the stage where crevices and rocks of the ocean bottom no longer afforded safe hiding for U-boats.

"VE" signalized the surrender of about $50 \mathrm{U}$-boats which were operating throughout the Atlantic and several score more were taken in ports. Thus, the Battle of the Atlantic had its finale with about $110 \mathrm{U}$-boats being taken out to sea and sunk in deep water.

The Japs now had about 70 oceangoing submarines which were employed primarily to supply their hard-pressed bases. Their speed of 22 knots surfaced and 8 knots submerged compared favorably with current submarines of other nations. They were pursued relentlessly by Allied anti-stbmarine groups, and by our own submarines.

The killing of six Jap subs in eleven days by the USS ENGLAND will probably be considered the war classic in anti-submarine warfare. On 19 May the destroyer escorts, USS ENGLAND, USS GEORGE, and USS RABY were on an offensive submarine hunt east of the Solomons Islands. The ships were spaced apart according to the assured sound range as derived from Bathythermograph analysis. Sonar echoes were obtained by USS ENGLAND at 1325 hours, but the contact seemed "doubtful", so ENGLAND made a run over the target for evaluation resulting in contact being classified as a Jap sub.

At 1340 a firing rur was made but none of the Hedgehog projectiles scored. (No depth charges were used.) On the second attack at 1350 two Hedgehog projectiles detonated. The third and fourth attacks were unsuccessful. On the fifth salvo at 1433 hours, three or four projectiles detonated. ENGLAND's fathometer indicated a submarine at a depth of 324 feet. Two minutes later a violent underwater explosion astern was so intense that several men on the fantail were knocked off their feet. At 1600 hours ENGLAND lowered a life boat near the center of the submarine's oil slick which was 300 yards wide and 2 miles long and obtained a mattress, broken furniture, etc., as evidence. No human remains were found but "that is explained by the fact that numerous large sharks were seen in the explosion area and the crews of the whaleboat had to actually fight them off while recovering wreckage."

The second action began 3 days later, on 22 May at 0350 hours, when GEORGE and ENGLAND made radar contact 7 miles ahead and maneuvered to "box" the target between them, but the enemy submerged before it was possible to engage with gunfire. GEORGE established sonar contact and attacked with Hedgehogs without results. At 0425 ENGLAND gained sonar contact and quickly carried out two Hedgehog attacks. On the second attack three projectiles detonated at a depth of 240 feet to be followed a few minutes later by a violent underwater explosion. A board identified as submarine deck planking floated by, and by dawn diese! oil was rising in large quantities. A four hour sonar search verified the disintegration of the Jap sub. 
The third action started the next morning (23 May) at 0604 when RABY made radar contact four miles distant. The sub dived and evaded all initial attacks, but at 0819 ENGLAND made sonar contact on the basis of information passed by GEORGE. ENGLAND immediately closed with Hedgehogs; on the second salvo eight or ten projectiles detonated, and $31 / 2$ minutes later there was a tremendous underwater explosion. The submarine killers took no chances of being fooled this explosion might be a ruse; the Jap may have discharged a delayed action bomb, pulled away to a safe distance while it exploded, then returned to the disturbed area which might provide protection against sonar detection - so the ENGLAND crossed the explosion point and dropped a load of depth charges. Deck planking, cork, and a block of wood (with Japanese lettering) were picked up. By 1242 the dead Jap had vomited up an oil slick 800 yards wide and five miles long.

The fourth action began early the next morning (24 May) at 0122 when GEORGE made radar contact at 17,000 yards, but when the range closed to 9000 yards the sub dived. At 0150 ENGLAND developed sonar contact and made two evaluation runs, the second resulting in a Fathometer reading on the sub at a depth of 180 feet. ENGLAND at once attacked with Hedgehogs, three projectiles detonated and resulted in a rumbling noise, but the characteristic violent explosion did not occur.

This Jap was more adept at evasive tactics than were the first three victims; the Sonar indicated that he turned and fishtailed at high speed, used his echo ranging to interfere with the ENGLAND's echo ranging at the crisis of the attack, and followed in the ENGLAND's wake where the disturbed water might provide some protection against Sonar detection. However, the Jap's destruction was verified by deck planking, a chopstick, wood with Japanese lettering, etc.

The fifth action started at 2304 on 26 May when RABY made radar contact at 15,000 yards on a surfaced sub heading for the killer group. ENGIAND maneuvered to gain position to fire torpedoes and illuminate the sub, but the Jap dived 4100 yards away. A few minutes later ENGLAND made sonar contact, made a single run, fired a Hedgehog salvo, and 4 to 6 detonations followed. Dawn revealed debris over a large area; articles obtained were: 14 pieces of deck planking marked with Jap lettering, pressed cork, part of a chronometer, etc. Number five Jap had joined his ancestors.

The sixth action began on 30 May which was spent by GEORGE and RABY in a number of attacks on rather doubtful contacts which appeared to be a reef, "but the Commander of the killer group had RABY maintain contact throughout the night with the "reef" which surfaced, in the form of a large Jap sub, at 0302 on 31 May between RABY and GEORGE who were oniy 4000 yards apart. Before the line of fire could be cleared, the Jap dived.

RABY, maintaining sonar contact, attacked with Hedgehog without results. GEORGE then maintained sonar contact, but did not attack, and held sonar contact till after sunrise when ENGLAND and SPANGLER (new comer) arrived. At 0649 GEORGE attacked with Hedgehog; results negative. At 0659 RABY tried; results negative. At 0713 SPANGLER attacked; results negative. At 0735 ENGLAND attacked; results 6 to 10 Hedgehog detonations followed shortly by a tremendous explosion. The usual evidence of planks, cork, etc., signified the end $f$ number six victim.

The ENGLAND's six kills in eleven days broke two world's records. Also remarkable is the fact that it was her first encounter with the enemy. The Commanding Officer, Lt. Cdr. W.B. Pendleton, USN, reported: "The team operated as a unit and functioned with little or no confusion. During the attacks, the Commanding Officer and the Executive were interchangeable at the conn and both obtained hits. Hits were obtained with three different sonar men on the stack (Sonar console). As on any anti-submarine team that functions properly, there were no stars."

During 1945 twenty-six Jap submarines were sunk. Only one Allied ship was sunk by the Japs between VE and VJ Days. 43 Jap submarines were taken as a result of VJ, the remainder of their submarines had been scuttled.

The terrific 72 months battle in which control of the seas was vitally essential to victory had cost the Allies about 4773 Merchant ships (21,141,000 gross tons) sunk by enemy action. During the war 996 Axis submarines were sunk, and 221 more plus scores of midgets were captured after enemy capitulations. Credit for sinking enemy submarines was assigned approximately to Britain for 70 per cent and to the United States for 30 per cent. 
In the last days of the war the Germans had developed their "submersibles" into a true submarine, which according to Gross Admiral Doenitz, "with its great range of 22,000 miles was capable of scouring all waters of importance for the U-boat war without having to surface." The German designers claimed outstandingly submerged speeds of 24 knots. Allied opinion is that, "It can out-distance and probably shake off any of our present escorts who attack it." Such submarines, plus homing torpedoes, may be with us for the rest of history; they can be built in secret, and are certain to be used by the smaller naval powers.

We barely won a war against submarines, and according to the enemy, "By superiority in the field of science." Let us heed the warning of Navy Secretary Forrestal, "That a military research program literally may be the price of survival", and provide enough funds to continue development, along with other sciences, of today's only effective detector of submerged submarines - SONAR. 


\section{APPENDIX}

Partial List of Universities, Institutions, and Industries Participating in the Sonar Program of World War II.

University of California

Scripps Institution of Oceanography

California Institute of Technology

University of Minnesota

State University of Iowa

University of Chicago

University of 'Wisconsin

University of Southern California

University of Pennsylvania

University of Pittsburgh

Yale University

University of Louisiana

Oregon State College

Brigham Young University

University of Texas

Dartmouth College

Harvard University

Columbia University

Rice Institute (Houston, Texas)

Case School of Applied Sciences

University of Illinois

Amherst College

Massachusetts Institute of Technology

University of Indiana

Washington University of St. Louis

American Steel \& Wire Company

Worcester, Mass.

American Type Founders Corporation

Elizabeth, N.J.

Bendix Aviation Corporation

Pacific Division, No. Hollywood, Calif.

David Bogen Company

New York, N.Y.

Boyland Boyce Company

New York, N.Y.

Bristol Company

Waterbury, Conn.

E.G. Budd Manufacturing Company

Philadelphiá, Pa.

General Electric Company

Schenectady, N.Y.

Harvey Radio Laboratory

Cambridge, Mass.

Hewlett Packard Company

Palo Alto, Calif.

Metal \& Glass Products Company

Chicágo, Ill.

National-Simplex-Bludworth, Inc. Bludworth Marine Div., New York, N.Y.

New Haven Clock Company

New Haven, Conn.

Presto Electric Company

New York, N.Y.

Radio Corporation of America

RCA Victor Division

Camden, N.J.
Sangamo Electric Company Springield, Ill.

Sound Equipment Corporation Glendale, Calif.

Submarine Signal Company Boston, Mass.

War Supplies, Ltd. Washington 5, D.C.

Wallace \& Tiernan Belleville, N.J.

Warwick Manufacturing Company Chicago, Ill.

Western Electric Company New York, N.Y.

Kato Engineering Company Mankato, Minn.

Gates Engineering Company Wilmington, Del.

Century Electric Company St. Louis, Mio.

Hertner Electric Company Cleveland, Ohio

Gorham Manufacturing Company

Providence, R.I.

United Cinephone Corporation

Torrington, Conn.

Bell Telephone Laboratories New York, N.Y.

Astatic Corporation Youngstown, Ohio

McKiernan Terry Corporation Belleville, N.J.

Brush Development Company Cleveland, Ohio

Rice-Barton Company Worcester, Mass.

Continental Can Company Syracuse, N.Y.

Strong Electric Company Toledo, Ohio

Stoddert Aircraft Radio Corporation Los Angeles, Calif.

Electrical Research Products Corp. New York, N.Y.

Freed Radio Corporation New York, N.Y.

F.W. Sickels Company Springfield, Mass.

Goodrich Rubber Company

Akron, Ohio

Line Material Company Stroudsburg, $\mathrm{Pa}$.

Bell Sound System

Columbus, Ohio

Many others who participated but are not mentioned were probably subcontracted by those listed above; however, their contributions were, in some cases, of equal magnitude and value. 
ILTISSTRATION A。

FIRST NAYY SOIAR - World War I complete SC listening apparatus. Water sounds activate 3 inch diameter rubber balls wich transfer sounds thru air filled acoustlo piping to stetboscope; worn by operator, who senters sound binauraliy by turning handie nor (12). Pointer on calibrated scale near (9) indicates direotion of target. No provisius for obtaining target's distance. " $T$ " shaped SC tubeg were hing cressiae or protruded thru bottom of Sibchesers.

\section{IILUSTRATION B.}

SHIP CROSS SECTION SHOWS SONAR ECIIPMENT - ThIS cross section of a combat ship shows Sonar Equipment lastailations, both in the pilot hise or control room, above, and beiow, in the lower sound room, in which the retractable gear and dome is located.

\section{ILIUSTRATION C.}

IODERN SUBMARINE IISTENTIL DONAR. Made之 "JP" IL Jienirg equipinent. TOpside hydrophone consiats of z- fout long magneto-strich wn tube (eleotmo-magnet). Sound waves striking the tube cause a uhazge in its nagha; c fux thereby generating a current which rasuits in afgnals corresponding to the sound source, i. e., propel er noise, eto. JF nas gow directional accuracy ju sumas up to about 10 miles distant in good water conditions.

\section{ILIUSTRATION D.}

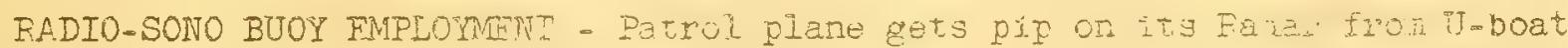

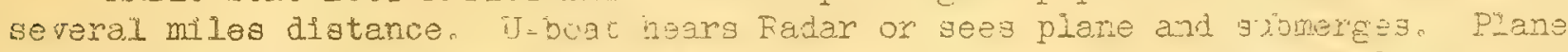
parachutes Radio-Sono Euoy Wiah wcats: Lets out Soner hydrophong pelon waters

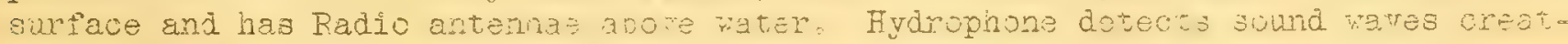

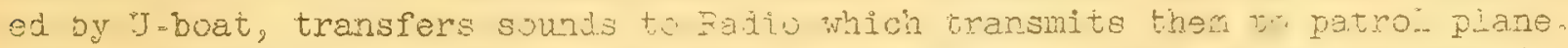
Depth charges may be dropped by piane. Several nore buoys maybe parachuted in

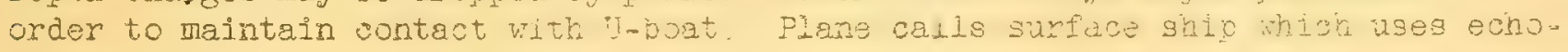
ranging Sonar to accurately locate and a,tack U-boat.

\section{ILLUSTRATION E.}

ECHO RANGING INSTALIATION IN MODERN SUBMARINE - The six panels constitute the "Sonar Stack" which embody the power controls, the "Dricrex" unich energizes the Transducer, the Feceiver-Ampitisp and its controls, the range and bearing indicators, etc. The two piliars at the left are the "TralnaHons" dontrol for the dome which may be retrapted into the Submarine. The Transdicar id 1nside the dome and may be rotated to any bearing desired.

IIIUSTRATION F。

SONAR GOES -A. FISHING - This bhark got too nosey and wos houkd os an escort vessel's Sonar dome while at sea and stayed hooked tzli the ship was drydocked. Ships with faulty bonar were nct very useful as escints, usuaity dropped out of convoy duty, and pus is at one of tne many bases for repairs. Necessary repair parts were often flown in order to heve every avalible Sonar equipped vessel at sea. 



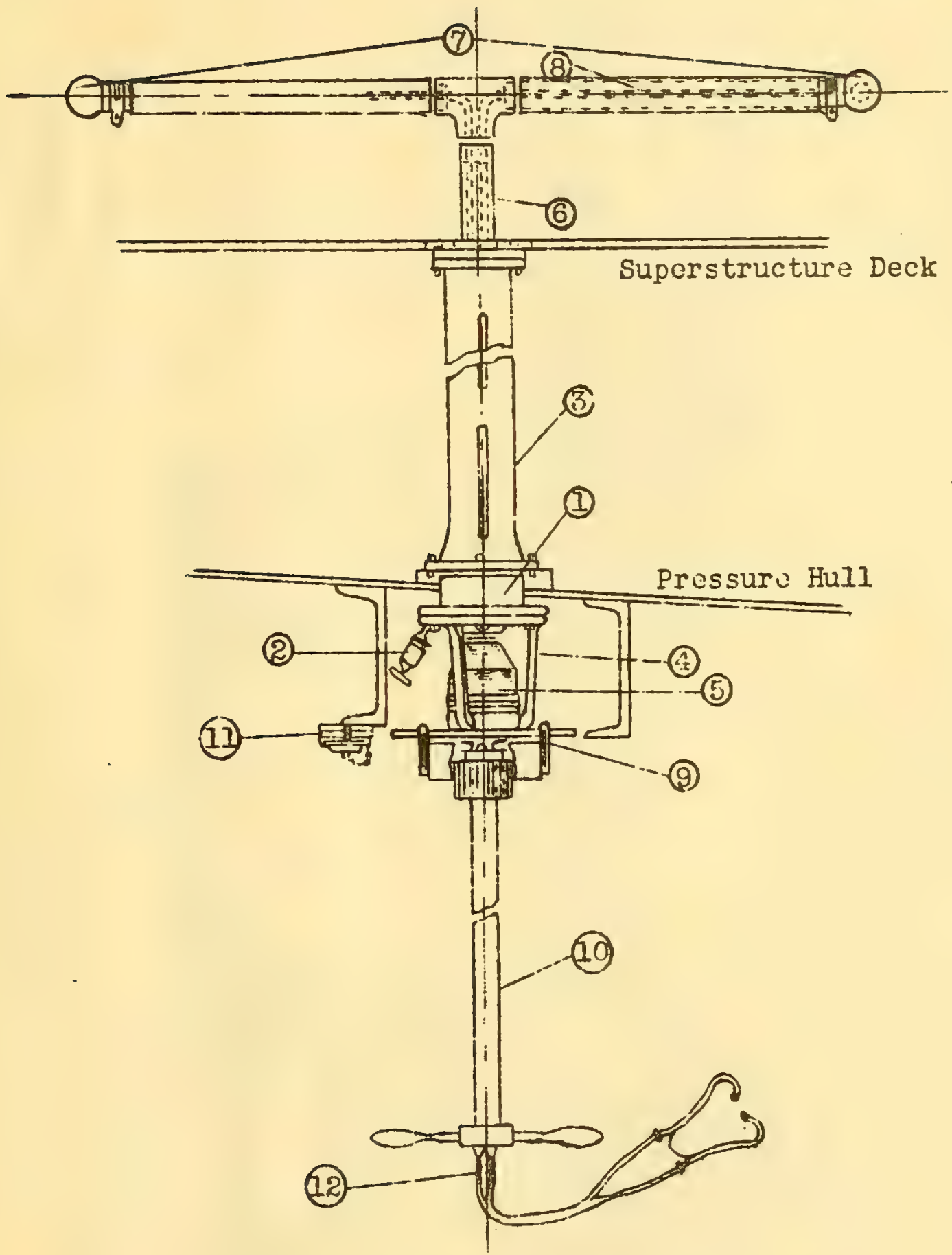

TYPE SE-4214 (SC) SOUND RECEIVER 

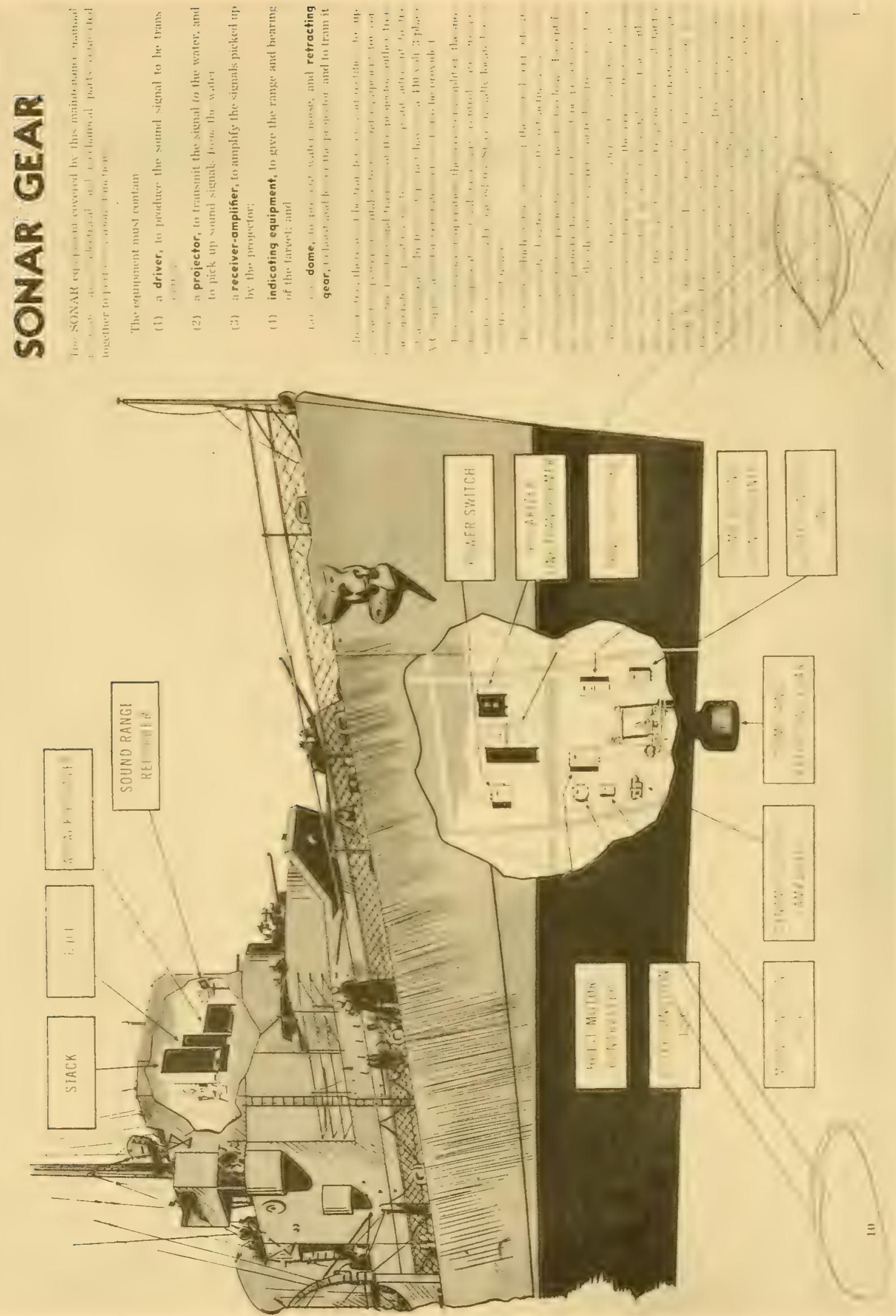


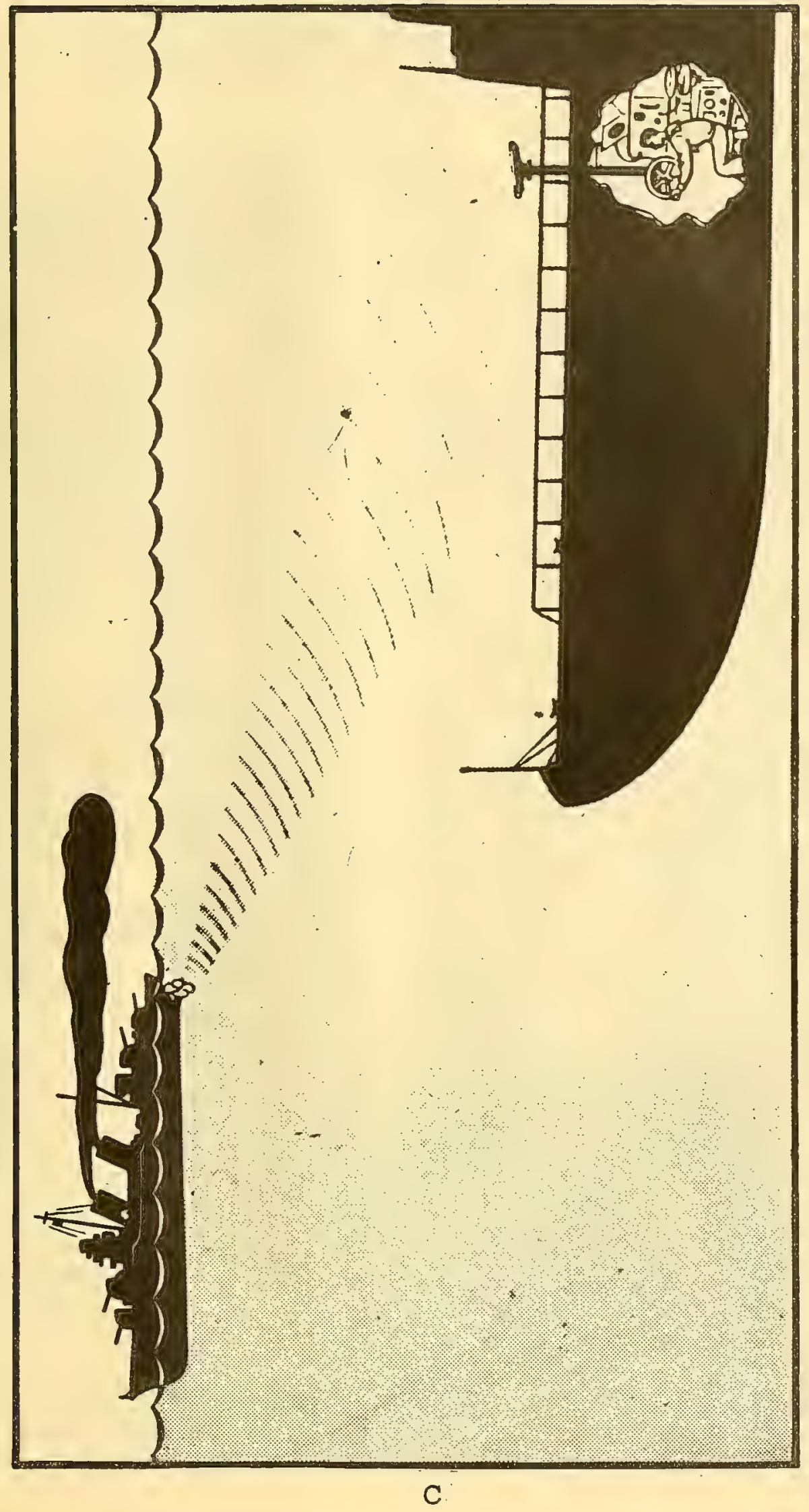




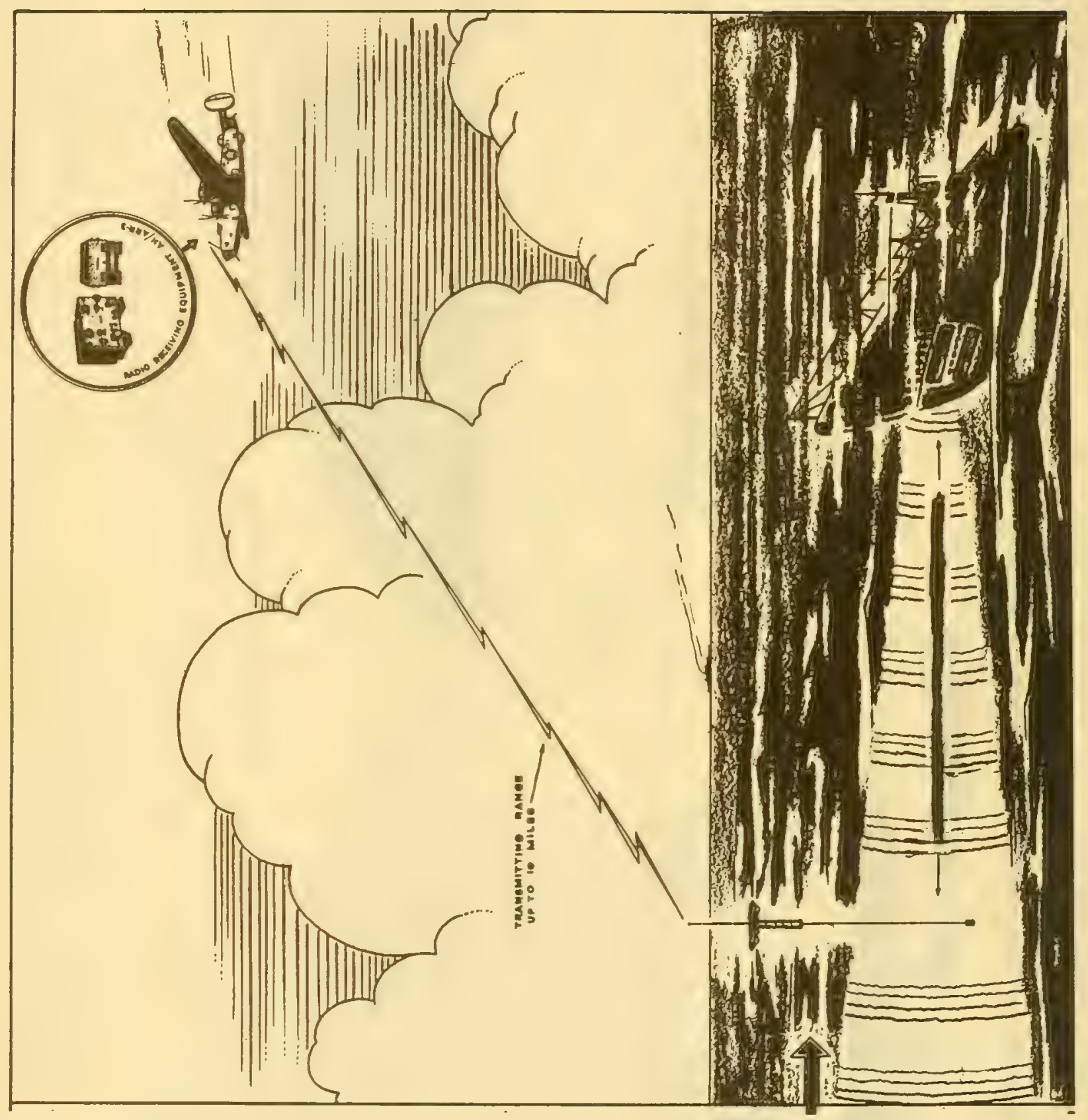



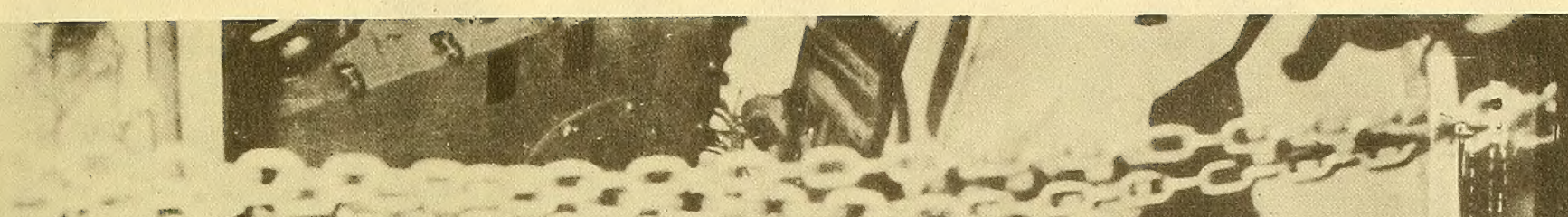

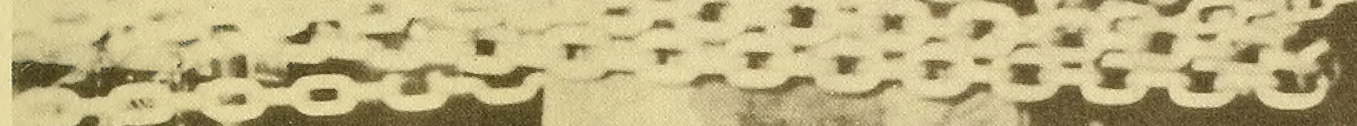

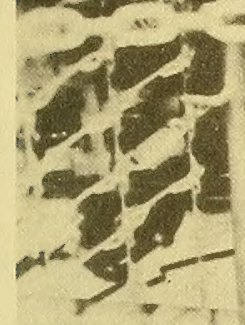

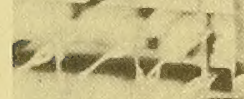

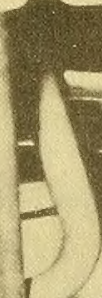
$-\frac{-1}{\gamma}$
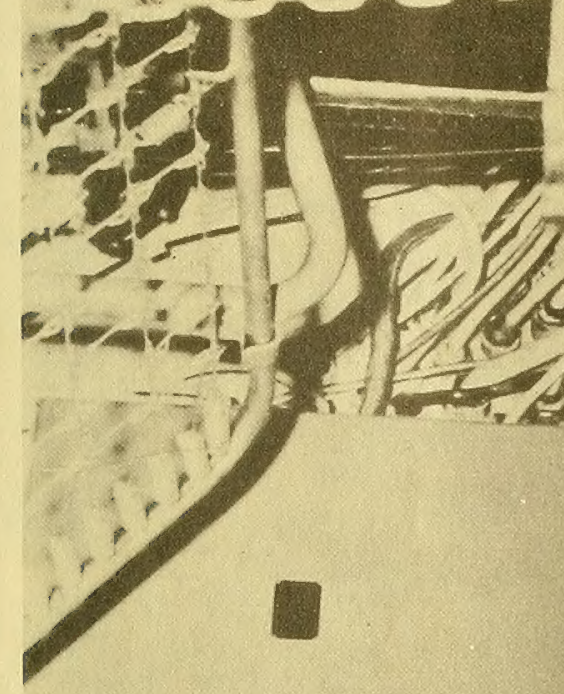

달
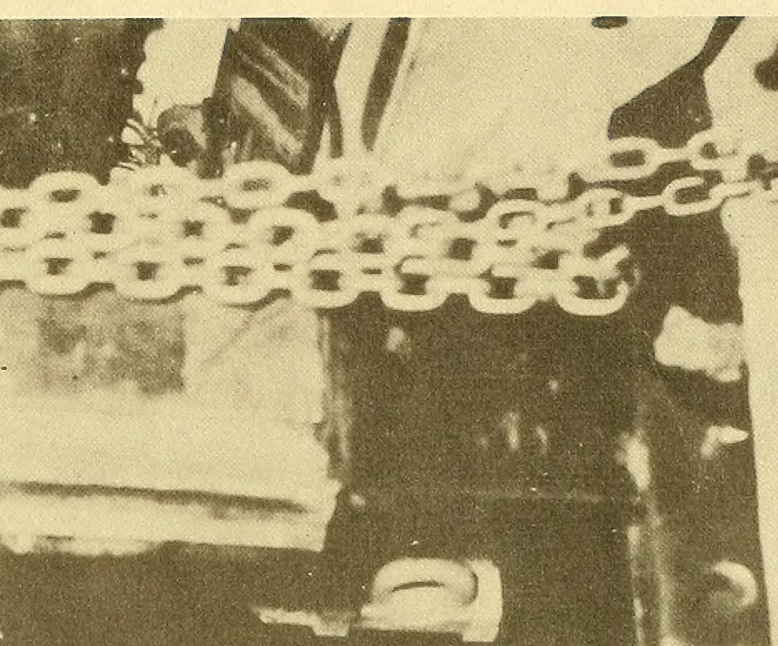

$\lim _{-\infty}$

ii

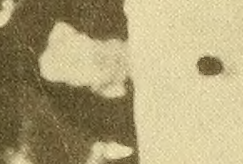

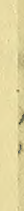

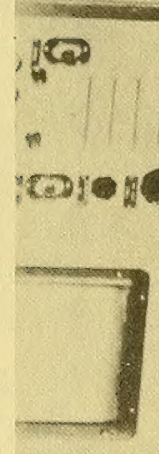

5
$5=1$
0

$\|+a a^{\infty}$
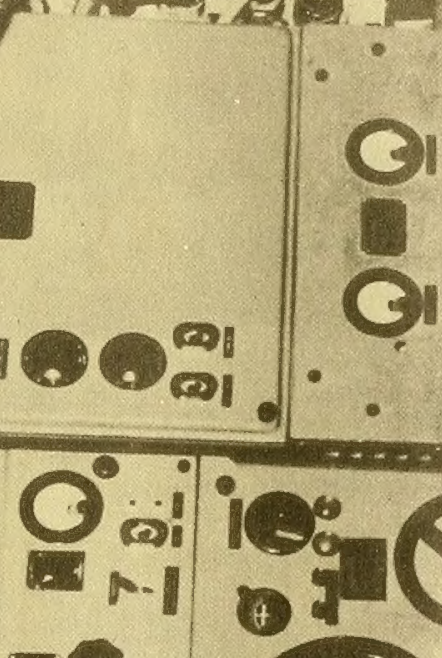

${ }^{2} \rightarrow c^{6}$

(5)

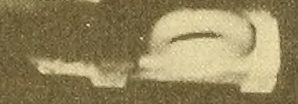

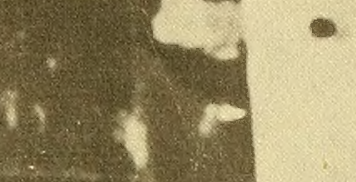
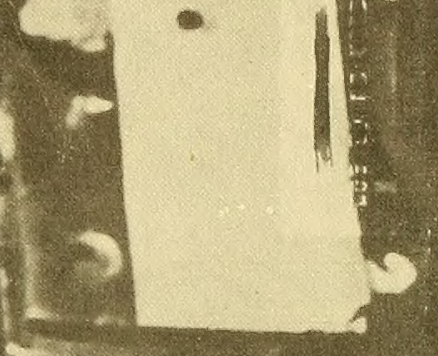

$>$

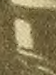

1

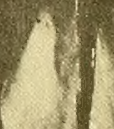

(3)

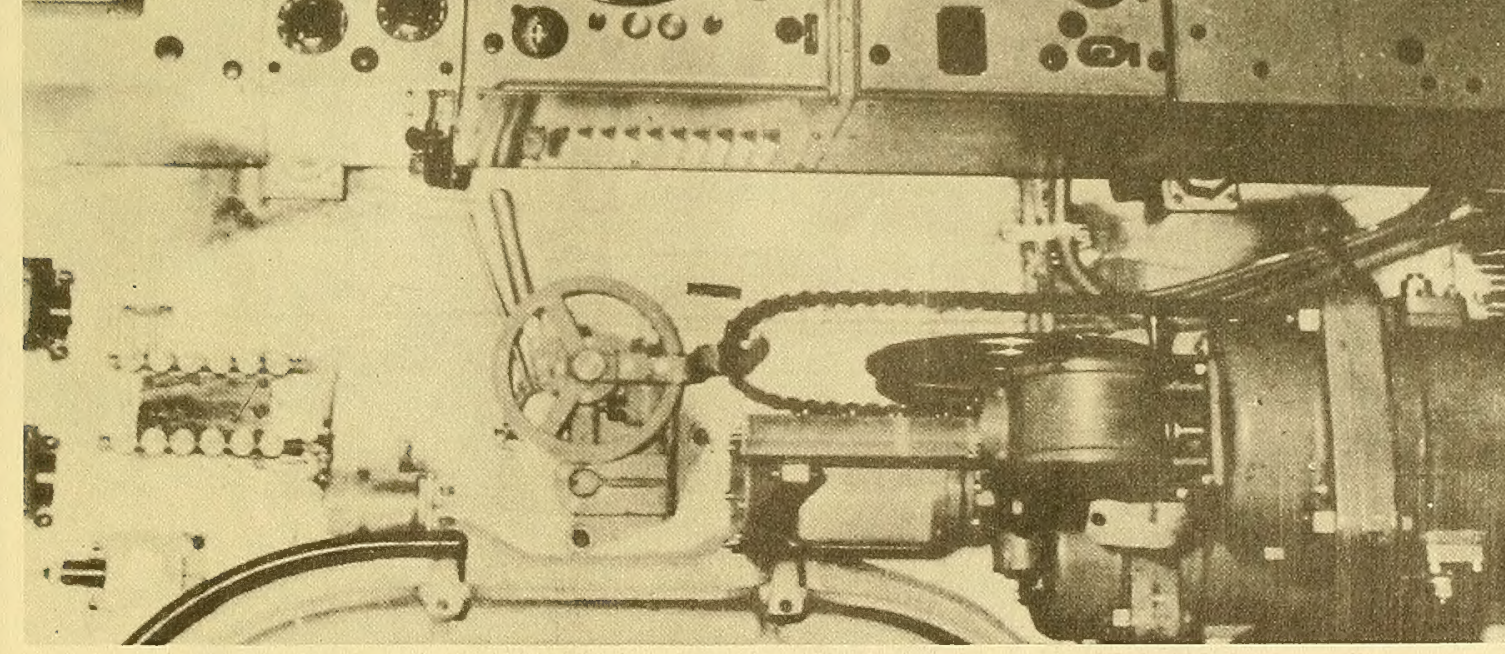

(1)

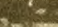

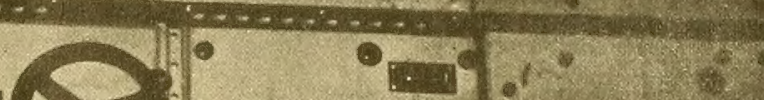




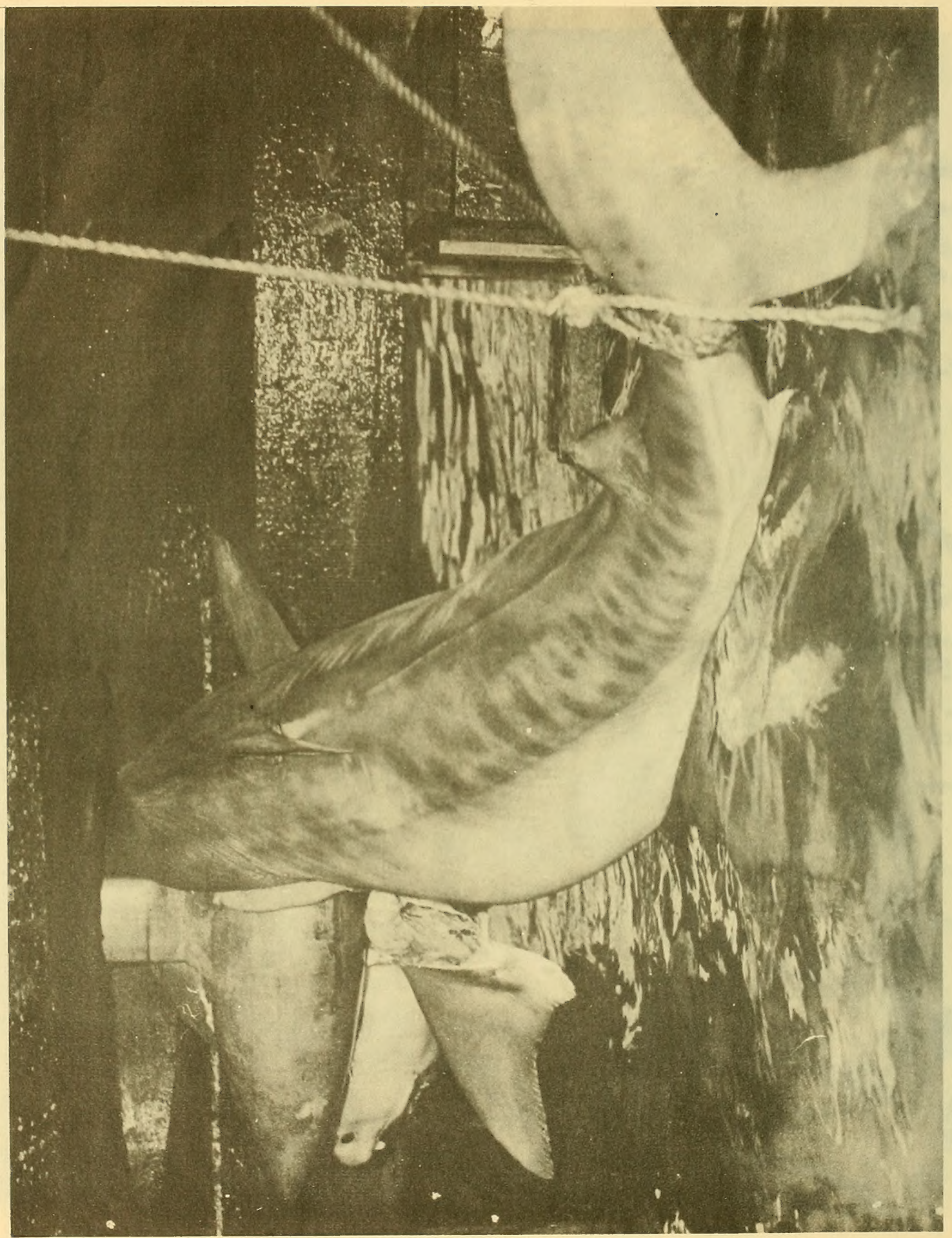



